\title{
Capillary Gel Electrophoretic Analysis of Cattle Breeds Based on Difference of DNA Mobility of Microsatellite Markers
}

\author{
Miji Lee, Duhak Yoon, ${ }^{\ddagger}$ Jin-Tae Jeon, ${ }^{\ddagger}$ Seong Kug Eo, ${ }^{\S}$ and Seong Ho Kang ${ }^{-}$ \\ Department of Chemistrv and Research Institute of Phusics and Chemistry (RINPAC),

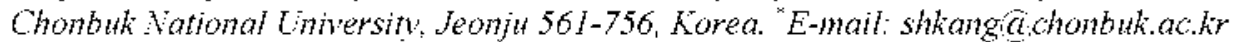 \\ thational Institute of Animal Science, Suwon $7+1$-706, Korea \\ ${ }^{\ddagger}$ Division of Applied Life Science (BK21 program), Gradhate School of Gyeongsang Kational Lniversity, \\ Jinju 660-701. Korea \\ Laboratory of Aficrobiology, College of I eterinary Hedicine, Chonbuk Kational Ciniversity, Jeonju 561-756, Korea \\ Received June 17, 2009, Accepted September 17, 2009
}

\begin{abstract}
A breed of cattle, i.e., Korean cattle (Hanwoo), was identified based on the DNA mobilities of their microsatellites (MSs) by capillary gel electrophoresis (CGE) with a laser-induced fluorescence (LIF) detector. The MS markers were used for the accurate identification of species-specific genes. The DNA mobilities of the MS markers of Hanwoo and Holstein were measured using a CGE system with a fused-silica capillary (inner diameter of $75 \mu \mathrm{m}$, outer diameter of $365 \mu \mathrm{m}$, and total length of $50 \mathrm{~cm})$. The capillary was dynamically coated with $1.0 \%(\mathrm{w} / \mathrm{v})$ polyvinylpyrrolidone $\left(H_{\mathrm{T}}=1,000,000\right)$ and then filled with a mixture of $1.3 \%(\mathrm{w} / \mathrm{v})$ poly (ethylene oxide) $\left(\mathrm{H} f_{\mathrm{r}}=600,000\right)$ and $1.9 \%(w / v)$ poly'(ethylene oxide) $\left(M_{1}=8,000,000\right)$ as a sieving gel matrix. The species-specific genes of Hanwoo and Holstein were clearly distinguished within $33 \mathrm{~min}$. This CGE assay technique is expected to be a useful analytical method for the fast and accurate identification of breeds of cattle
\end{abstract}

Key Words: Cattle breed. Microsatellite. Capillary gel electrophoresis. DNA mobility

\section{Introduction}

Bovine spongiform encephalopathy (BSE) is a kind of transmissible spongiform encephalopathy (TSE) in cattle. A considerable amount of research is being conducted into this disease in a variety of bovines. because BSE can be transmitted to human beings in the form of its variant. Creutzfeldt-Jakob disease (vCJD) ${ }^{1,2}$ BSE has arisen in many countries, including France (number of cases of BSE. 993). Germany (415). Japan (34), the United Kingdom (181 591), the United States of America (2) and many others according to the Office International des Epizooties (OIE). Due to the impact of the free trade agreement (FTA) and various changes in international trade. the import and export of bovine exposed to BSE has become a major risk. Therefore. the development of fast and accurate identification methods for species-specific genes of cattle is increasing.

According to the existing theory. the breed of Korean cattle called Hanwoo was formed by the hybridization of Bos Taurus (ethnic European) and Bos Zebu (ethnic Indian) about four thousand years ago. ${ }^{3}$ It was introduced into Korea from Manchuria after hybridization in Outer Mongolia. a region of northern China. However. there is also an alternative theory based on microsatellite marker analysis, suggesting that it originated only from Bos Taunis. ${ }^{+5}$ Until now. breeds of Korean cattle have been distinguished based on their appearance. because it is not easy to establish a scientific detection method.

Recently. the identification of cattle species has been accomplished using various methods. including restriction fragment length polymorphisms (RFLPs) ${ }^{48}$ random amplified polymorphic DNAs (RAPDs), ${ }^{9,10}$ amplified fragment length polymorphisms (AFLPs) ${ }^{11.12}$ and simple sequence repeat polymorphisms (SSRs) or microsatellites (MSs). ${ }^{1 .+15}$ These methods detect poly- morphisms by assaying subsets of the total amount of DNA sequence variation in a genome. For example. RFLPs can be readily and directly detected as the differences in the length of DNA fragments after digestion with DNA sequence specific restriction endonucleases. However. RFLPs reveal the lack of polymorphisms for some species ${ }^{16,17}$ RAPDs use markers formed from 10 mer oligonucleotides of arbitrary sequences for the amplification of DNA fragments. ${ }^{17,18}$ Oh et al. showed accuracy of RAPDs method that the specific band is absent in 644 of 673 Hanwoo (96\%), but present in 245 of 256 Holstein $(95 \%) .{ }^{117}$ Although the accuracy of RAPDs is high it shows low reproducibility on account of the sensitivity of $\mathrm{PCR}$ amplification. ${ }^{11}$ AFLPs use restriction enzymes to cut genomic DNA. followed by the ligation of the adaptors to the sticky ends of the restriction fragments. ${ }^{1.9} \mathrm{AFLPs}$ are highly sensitive tool, and besides the reproducibility of AFLPs is higher than that of RAPDs. However. both of these techniques are dominant and low informative. ${ }^{1,1,17}$ MSs are polymorphic loci present in nuclear and organellar DNA that consist of repeating units consisting of $1-6$ base pairs. ${ }^{13.15}$ MS markers are particularly useful due to their high diversity and ease of detection by polymerase chain reaction (PCR). They are most abundant in eukaryotic genomes and unifornly distributed along a genome. SSRs or MSs are highly variable and codominant. therefore their information value is higher than that of other markers such as RFLPs, RAPDs and AFLPs. ${ }^{3 i 1}$ Also, a in previous investigation we identified Honwoo witlin 4 min using the single nucleotide polymorphism (SNP) markers. ${ }^{22}$ Although the SNP method showed a fast analysis time. its accuracy was low comparable to that obtained using MS markers ( $\rightarrow 99 \%)^{\text {?. }}{ }^{? 2}$

In this study as a model case. we analyzed the genetic differences between Hanwoo and Holstein by the gene analysis 
Table 1. Information of the MS markers analyzed

\begin{tabular}{|c|c|c|c|c|}
\hline Locus & $\begin{array}{c}\text { Number of Alleles } \\
(\text { Hanwoo })\end{array}$ & Size range $(b p)$ & & Primer Sequence $\left(5^{\prime}-3^{\prime}\right)$ \\
\hline ETH3 & 6 & $103-131$ & $\begin{array}{l}\mathrm{F} \\
\mathrm{R}\end{array}$ & $\begin{array}{l}\text { GAACCT GCC TCT CCT GCA TTG G } \\
\text { ACT CTG CCT GTG GCC AAG TAG }\end{array}$ \\
\hline $\mathrm{ETH} 225$ & 6 & $138-168$ & $\begin{array}{l}F \\
R\end{array}$ & $\begin{array}{l}\text { GAT CAC CTT GCC ACT ATT TCC T } \\
\text { ACA TGACAG CCA GCT GCT ACT }\end{array}$ \\
\hline $\mathrm{BM} 1824$ & 6 & $178-194$ & $\begin{array}{l}\mathrm{F} \\
\mathrm{R}\end{array}$ & $\begin{array}{l}\text { GAG CAA GGT GTT TTT CCA ATC } \\
\text { CAT TCT CCAACT GCT TCC TTG }\end{array}$ \\
\hline TGLA126 & 7 & $111-129$ & $\begin{array}{l}\mathrm{F} \\
\mathrm{R}\end{array}$ & $\begin{array}{l}\text { CTA ATT TAG AAT GAG AGA GGC TTC T } \\
\text { TTG GTC TCT ATT CTC TGAATA TTC C }\end{array}$ \\
\hline TGLA 122 & 8 & $134-190$ & $\begin{array}{l}F \\
R\end{array}$ & $\begin{array}{l}\text { CCC TCC TCC AGG TAA ATC AGC } \\
\text { AAT CAC ATG GCA AAT AAG TAC ATAC }\end{array}$ \\
\hline TGLA227 & 4 & $78-106$ & $\begin{array}{l}F \\
R\end{array}$ & $\begin{array}{l}\text { CGA ATT CCA AAT CTG TTA ATT TGC T } \\
\text { ACA GAC AGA AAC TCA ATG AAA GCA }\end{array}$ \\
\hline $\mathrm{BM} 2113$ & 7 & $116-150$ & $\begin{array}{l}F \\
R\end{array}$ & $\begin{array}{l}\text { GCT GCC TTC TAC CAAATA CCC } \\
\text { CTT CCT GAG AGAAGC AAC ACC }\end{array}$ \\
\hline ETH10 & 6 & $210-226$ & $\begin{array}{l}\mathrm{F} \\
\mathrm{R}\end{array}$ & $\begin{array}{l}\text { GTT CAG GAC TGG CCC TGC TAA CA } \\
\text { CCT CCA GCC CAC TTT CTC TTC TC }\end{array}$ \\
\hline SPS115 & 7 & $245-261$ & $\begin{array}{l}F \\
R\end{array}$ & $\begin{array}{l}\text { AAA GTG ACA CAA CAG CTT CTC CAG } \\
\text { AAC GAG TGT CCT AGT TTG GCT GTG }\end{array}$ \\
\hline
\end{tabular}

$F=$ forward primer. $R=$ reverse primer

technique using MS markers. A 2-bp DNA allelic ladder was amplified by five MS markers (TGLA227. BM2113, TGLA53, ETH10. and SPS 115). Both Hanwoo and Holstein were amplified by the nine MS markers shown in Table 1. These were selected as the best out of the many MS markers which are recommended for bovine patemity tests by the International Society for Animal Genetics (ISAG). ${ }^{24.35}$ The selected MS markers gave rise to high polymorphism and species-specific bands for Hanwoo and Holstein. ${ }^{2}$ After the PCR amplification of the MS markers. CGE analysis based on DNA mobility using an LIF detector was performed for the highly sensitive and selective detection of Hanwoo genes.

\section{Experimental Section}

Chemicals and reagents. The single strength $(\mathrm{l} \times)$ TBE buffer solution was prepared by dissolving a pre-mixed powder (Amresco. Solon. OH. USA) containing $0.089 \mathrm{M}$ Tris. 0.089 $\mathrm{M}$ borate and $0.002 \mathrm{M}$ EDTA $(\mathrm{pH} 8.45)$ in deionized water. The dynamic coating matrix for the gel electrophoresis was made by dissolving $1.0 \%(\mathrm{w} / \mathrm{v})$ of poly vinylpyrrolidone (PVP. $M_{\mathrm{t}}=1,000.000$ ) (Polyscience, Warrington, England) in the $1 \times$ TBE buffer along with $0.5 \mu \mathrm{g} / \mathrm{mL}$ ethidium bromide ( $\mathrm{EtBr}$. Molecular Probes. Eugene. Oregon, USA). The solution was subjected to rocking until the bubbles disappeared. The sieving matrices were made by dissolving $1.3 \%$ (w/v) of poly (etlyylene oxide) (PEO. $\left.M_{\mathrm{i}}=600,000\right)$ and $1.9 \%(\mathrm{w} / \mathrm{v})$ of PEO $\left(M_{\mathrm{s}}=\right.$ $8.000,000$ ) (Sigma. St. Louis. MO. USA) in the $1 \times$ TBE buffer along with $0.5 \mu \mathrm{g} / \mathrm{mL}$ EtBr. The mixed polymer was stirred vigorously at first and then slowly ovemight to obtain a homo-

\section{geneous mixture}

Preparation of samples. Hanwoo and Holstein DNA santples were received from the National Institute of Animal Science in Korea. They consisted of genomic DNA extracted from the muscles using a wizard genomic DNA purification kit (Promega, Madison. Wisconsin. USA) and amplified by PCR. The PCR reaction mixture consisted of a total volumie of $15 \mu \mathrm{L}$ with $1.5 \mu \mathrm{L}$ of $10 \times$ reaction buffer. $1.5 \mu \mathrm{L}$ of dNTPs mixture containing a concentration of $2.5 \mathrm{mM} .8 .25 \mu \mathrm{L}$ of forward and reverse primer mix. $0.375 \mu \mathrm{L}$ of HotStart DNA Polymerase (Bioneer. Daejeon. Korea) 1.175 $\mu \mathrm{L}$ of distilled water and $1.95 \mu \mathrm{L}$ of the purified DNA sample. The PCR profile was as follows: one cycle of incubation at $95{ }^{\circ} \mathrm{C}$ for $15 \mathrm{~min}$ and 5 cycles of denaturation at $94^{\circ} \mathrm{C}$ for $60 \mathrm{~s}$, annealing at $58{ }^{\circ} \mathrm{C}$ for $75 \mathrm{~s}$. extension at $72^{\circ} \mathrm{C}$ for $60 \mathrm{~s}$ and 5 cycles of denaturation at $94^{\circ} \mathrm{C}$ for $60 \mathrm{~s}$. annealing at $57^{\circ} \mathrm{C}$ for $75 \mathrm{~s}$. extension at $72^{\circ} \mathrm{C}$ for $60 \mathrm{~s}$ and $25 \mathrm{cycles}$ of denaturation at $94^{\circ} \mathrm{C}$ for $60 \mathrm{~s}$. annealing at $56^{\circ} \mathrm{C}$ for $75 \mathrm{~s}$. extension at $72{ }^{\circ} \mathrm{C}$ for $60 \mathrm{~s}$ and extension at 65 ${ }^{\circ} \mathrm{C}$ for 30 min. The resulting solution was kept at $8^{\circ} \mathrm{C}$.

Capillary gel electophoretic identification. The experimental home-made CGE sy'stem with LIF detector was similar to that described previously. ${ }^{2-}$ Briefly, a diode-pumped solid-state laser ( $\lambda_{\mathrm{ex}}=532 \mathrm{~mm}$ : Power Technology Inc.. Alexander. AR. USA) was used as the light source in the CGE system. which was coupled to an LIF detector. A Bertan ARB 30 high-voltage power supply (Bertan High Voltage Inc., New York. USA) was used to drive the electrophoresis. A $50 \mathrm{~cm}$ total length $(30 \mathrm{~cm}$ effective length). $75 \mu \mathrm{m}$ inner diameter and $365 \mu \mathrm{m}$ outer diameter bare fused-silica capillary (Polynicro Technologies, LLC, Phoenix. AZ, USA) was used as a separation capillary. The 
running buffer was made up of $1 \times$ TBE buffer along with 0.5 $\mu \mathrm{g} / \mathrm{mL}$ EtBr. Both the coating and sieving matrix were hydrodynamically injected at one end of the capillary through a syringe. After the sample was injected electrokinetically at $60 \mathrm{~V} / \mathrm{cm}$ for $20 \mathrm{~s}$. sarmple separation was performed in an electric field of $120 \mathrm{~V} / \mathrm{cm}$. After each run, the capillary was reconditioned before the next analysis by rinsing it successively in water. $0.1 \mathrm{M} \mathrm{NaOH}$, water and the running buffer. The data was recorded as a function of time during the CGE, and saved on a Samsung computer (1.50-GHz Mobile Pentium M) at $5 \mathrm{~Hz}$. Data output and analysis were performed using Lab view (version 6. 1. National Instruments. Austin. USA).

\section{Results and Discussion}

We carried out the separation of a 2-bp DNA allelic ladder with a size range of $82-257$ op as the standard for the accurate identification of Hanwoo. The separation conditions such as the capillary effective length. electric field. composition and concentration of the separation media were varied to determine the optimum conditions. Increasing the capillary effective length was found to increase the resolution, but gave rise to broader peaks and an increase of the migration time (Fig. 1). The resolution can be enhanced by optimizing the capillary effective length (i.e.. $R_{\mathrm{s}}$ of peaks 23 and $24=1.45$ and $R_{\mathrm{s}}$ of peaks 24 and $25=1.77$ with an effective length of $30 \mathrm{~cm}$ ). Increasing the electric field strength increased the velocity of the DNA fragments and reduced the migration times. leading to shorter analysis times (Fig. 2). However. higher voltages led to higher currents and increased the Joule heating. Increased heat in the capillary may lead to broader peaks. non-reproducible migration times, sample decomposition or even the boiling of the buffer. which can cause electrical discontinuity throughout the capillary, thereby shutting down the CGE system. 251,253 and 257 bp DNAs (i.e., peaks 53,54 and 55) were not separated when using electric fields of over $120 \mathrm{~V} / \mathrm{cm}$. By using an electric field of $120 \mathrm{~V} / \mathrm{cm}$, however. the DNA molecules can be separated into three peaks within a relatively short time.

Because adsorption may cause broad and tailing peaks. ${ }^{26}$ the capillary inner wall was treated to eliminate electroosmotic flow and minimize adsorption by dynamically coating it with $1.0 \%(\mathrm{~W} / \mathrm{v})$ PVP $\left(M_{\mathrm{T}}=1,000,000\right)$. In a CGE system the composition and concentration of the separation media have an effect on the separation of the DNA molecules. There are pores within these gels and, as the charged solutes migrate through the gel-filled capillary, they are separated by a molecular sieving mechanism on the basis of their sizes. "Firstly we investigated the molecular sieving mechanism using a gel polymer with a single molecular weight. However we could not obtain good separation results (data not shown). Therefore. mixed sieving gel polymers with different molecular weights were used to separate the DNA molecules with a size range of $82-257 \mathrm{bp}$. This is because short-chain polymers interact preferentially with small DNA molecules. while long-chain polymers interact preferentially with large DNA molecules. ${ }^{28}$ In the mixed gel polymer șy'stem, increasing the molecular weight of the poly'mer gave rise to an increase in the resolution (Figs. 3 and 4). The

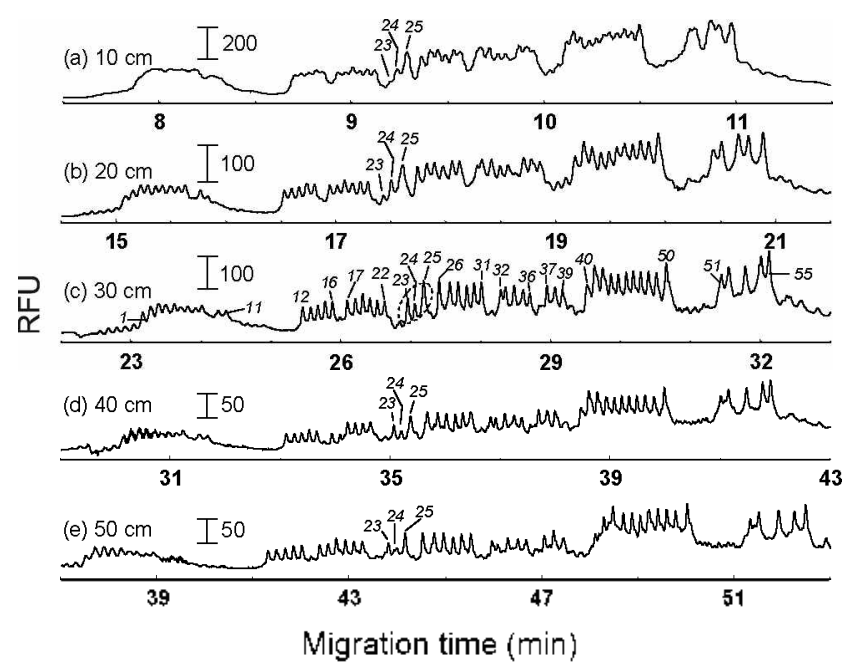

Figure 1. Representative CGE electropherograms of the PCR products of the 2-bp DNA allelic ladder with various DNA sequences of TGLA227, BM2113, TGLA53, ETH10 and SPS115. CGE separation conditions: fused-silica capillary, $75 \mu \mathrm{m}$ I.D. $\times 365 \mu \mathrm{m}$ O.D.; total lengths, $30,40,50,60$ and $70 \mathrm{~cm}$ : effective lengths, $10,20,30,40$ and $50 \mathrm{~cm}$; runting buffer, $1 \times$ TBE buffer $(\mathrm{pH} 8.45)$ with $0.5 \mathrm{ppm} \mathrm{EtBr}$; coating gel matrix, $1.0 \%$ PVP $\left(H H_{t}=1,000,000\right)$ in runing buffer; sieving gel matrix, a mixture of $1.3 \% \mathrm{PEO}\left(\mathrm{H} \psi_{\mathrm{r}}=600,000\right)$ and $1.9 \%$ PEO $\left(\mu_{\mathrm{r}}=8,000,000\right)$ in running buffer. sample injection, electrokinetic injection for $20 \mathrm{~s}$ at $60 \mathrm{~V} / \mathrm{cm}$ : applied separation electric field, $120 \mathrm{~V} / \mathrm{cm}$. RFU: relative fluorescence unit. *Indicate: $1=82$ bp, $11=105 \mathrm{bp}, 12=125 \mathrm{bp}, 23=154 \mathrm{bp}, 24=156 \mathrm{bp}, 25=158 \mathrm{bp}$, $39=192 \mathrm{bp}, 40=209 \mathrm{bp}, 50=228 \mathrm{bp}, 5 \mathrm{l}=246 \mathrm{bp}$, and $55=257 \mathrm{bp}$.

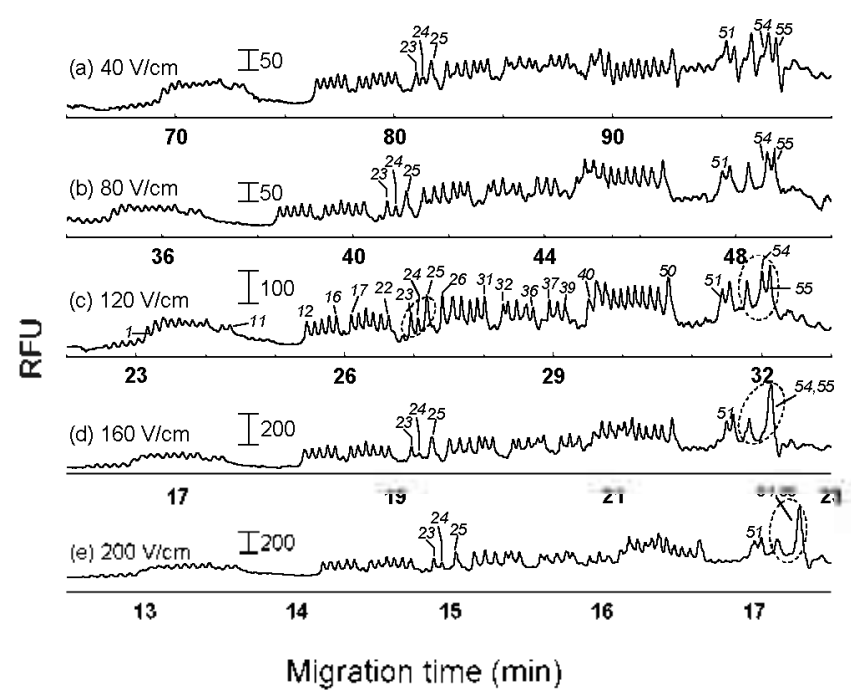

Figure 2. CGE electropherograms describing the effect of the electric field on the separation. CGE separation conditions: fused-silica capillary, $75 \mu \mathrm{m}$ I.D. $\times 365 \mu \mathrm{m}$ O.D., total length $50 \mathrm{~cm}$, effective length $30 \mathrm{~cm}$; applied separation electric fields, $40,80,120,160$ and $200 \mathrm{~V} / \mathrm{cm}$. The other conditions used were the same as those shown in Fig. 1.

differences in the resolutions of the 154,156 and 158 bp DNAs (i.e.. peaks 23.24 and 25 ) are shown in Table 2. However, using too high a molecular weight led to broader peaks and nonreproducible migration times. As a result. we carried out the experiments with a gel mixture consisting of $1.3 \%(\mathrm{w} / \mathrm{v}) \mathrm{PEO}$ 


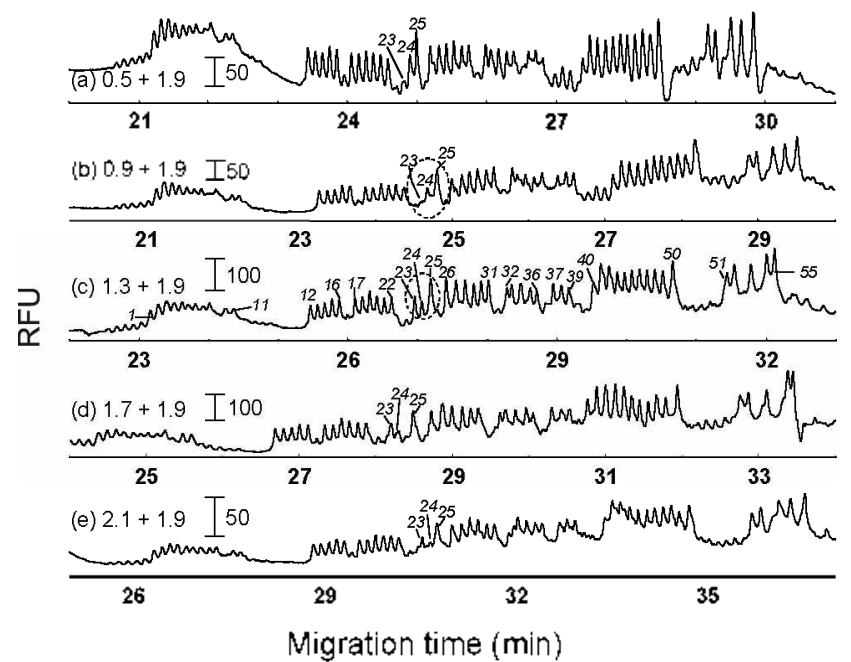

Figure 3. CGE electropherograms describing the eftect of the PEO $\left(M_{\mathrm{r}}=600,000\right)$ concentration on the separation. CGE separation conditions: applied separation electric field, $120 \mathrm{~V} / \mathrm{cm}$, sieving gel matrix concentrations, $0.5 \%, 0.9 \%, 1.3 \%, 1.7 \%$ and $2.1 \% \mathrm{PEO}\left(\mathrm{K} \mu_{1}=600,000\right)$ $+1.9 \% \mathrm{PEO}\left(\mathrm{M} \mu_{1}=8,000,000\right)$ in numing buffer. The other conditions used were the same as those shown in Fig. 2 .

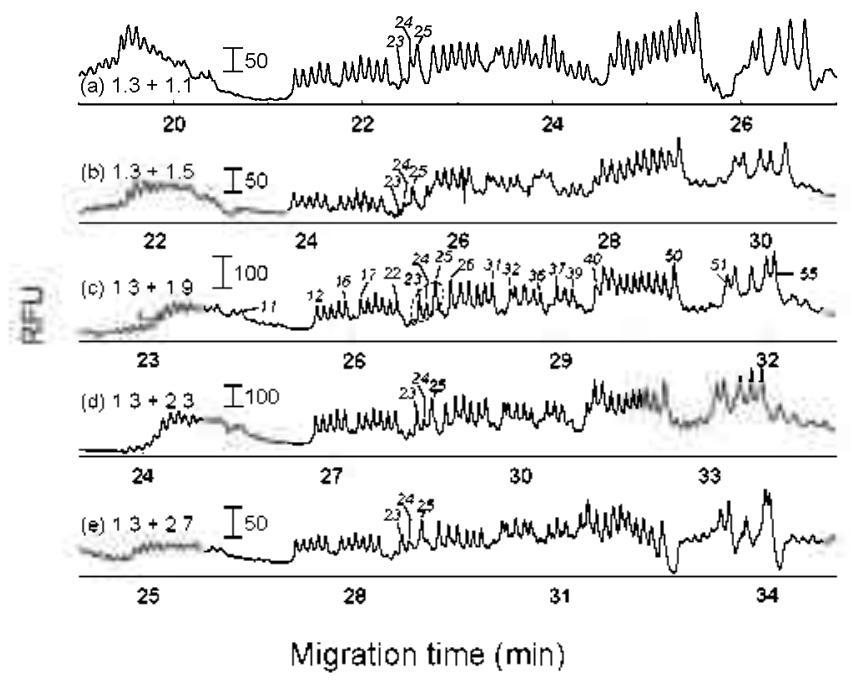

Figure 4. CGE electropherograms describing the eftect of the PEO $\left(\mathrm{A} f_{\mathrm{T}}=8,000,000\right)$ concentration on the separation. CGE separation conditions: sieving gel matrix concentrations, $1.3 \% \mathrm{PEO}\left(1 \mu_{\mathrm{T}}=600,000\right)$ $+1.1 \%, 1.5 \%, 1.9 \%, 2.3 \%$ and $2.7 \%$ PEO $(M=8,000,000)$ in runuing buffer. The other conditions used were the same as those shown in Fig. 3.

$\left(H_{\mathrm{r}}=600.000\right)$ and $1.9 \%(\mathrm{w} / \mathrm{v}) \mathrm{PEO}\left(\mathrm{H}_{\mathrm{r}}=8.000 .000\right)$ as the optimum sieving gel matrix.

The optimum conditions of the sieving gel matrix for the 2-bp DNA allelic ladder were found to be a total length of 50 $\mathrm{cm}$. electric field of $120 \mathrm{~V} / \mathrm{cm}$. and a mixture of $1.3 \%(\mathrm{w} / \mathrm{v})$ $\mathrm{PEO}$ and $1.9 \%(\mathrm{w} / \mathrm{v}) \mathrm{PEO}$. Table 3 shows the migration times (mean \pm standard deviation. $n=3$ ) of the 2-bp DNA ladder in the experiment conducted to confirm the reproducibility. for which the standard deviations were less than 0.04. A serial gap of 2-bp DNA allelic ladder was separated with a migration time interval of $8 \mathrm{~s}$. Under the optimum separation conditions.

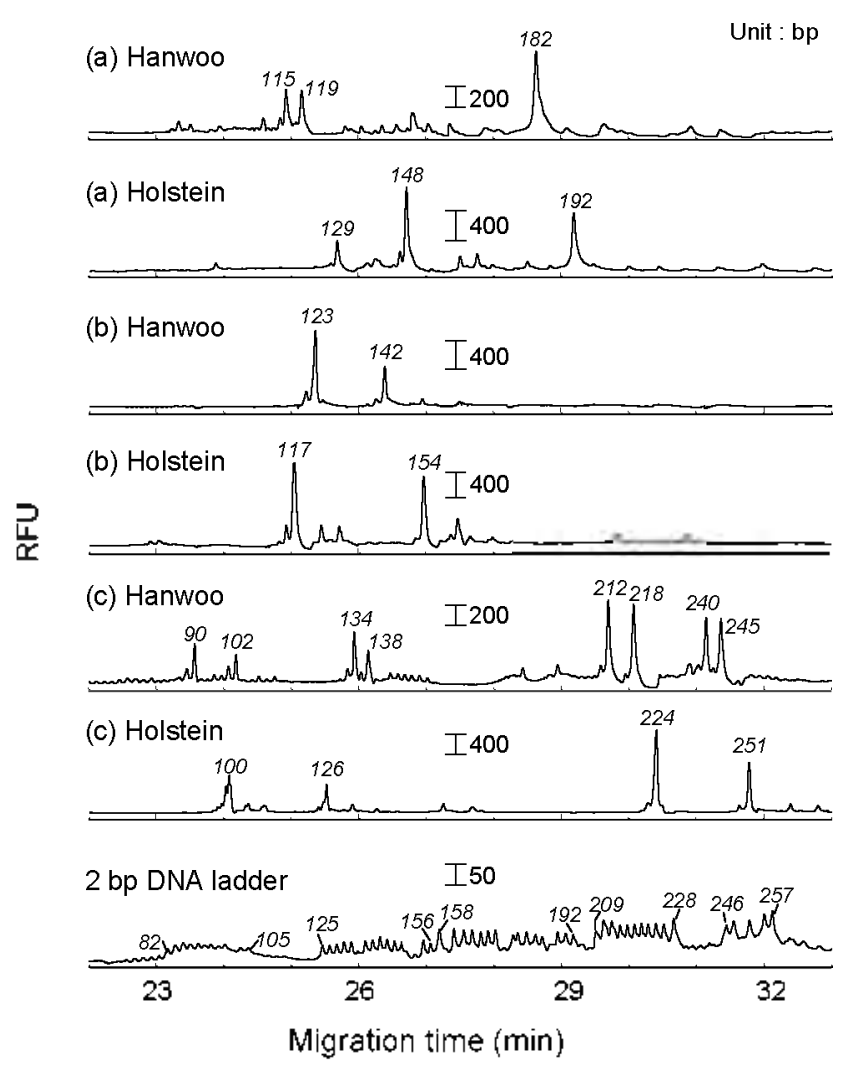

Figure 5. Representative CGE electropherograms of the PCR products of Hanwoo and Holstein. CGE separation conditions: sieving matrix, a mixture of $1.3 \% \mathrm{PEO}\left(\mathrm{H} \mu_{\mathrm{r}}=600,000\right)$ and $1.9 \% \mathrm{PEO}\left(\mathrm{M} \mu_{\mathrm{r}}=\right.$ $8,000,000 \mathrm{j}$ in running buffer. The other conditions used were the same as those shown in Fig. 4. MS markers (a) ETH3, ETH225, BM1824; (b) TGLA126, TGLA122: (C) TGLA227, BM2113, ETH10, SPS115.

Table 2. Resolutions $\left(R_{i}\right)$ of 154,156 and 158 bp DNAs (i.e., peaks 23,24 and $25 j$ at various sieving gel concentrations of the mixture polymer of $\mathrm{PEO}$

\begin{tabular}{ccc}
\hline PEO $(\%)^{a}$ & $\begin{array}{c}R_{z} \text { of peaks } \\
23 \text { and } 24\end{array}$ & $\begin{array}{c}R_{s} \text { of peaks } \\
24 \text { and } 25\end{array}$ \\
\hline $0.5 / 1.9$ & - & 1.26 \\
$0.9 / 1.9$ & - & 1.63 \\
$1.3 / 1.9$ & 1.52 & 1.77 \\
$1.7 / 1.9$ & 1.14 & 1.98 \\
$2.1 / 1.9$ & 2.25 & 1.35 \\
$1.3 / 1.1$ & - & 0.95 \\
$1.3 / 1.5$ & 0.96 & 1.51 \\
$1.3 / 1.9$ & 1.52 & 1.77 \\
$1.3 / 2.3$ & 1.54 & 1.65 \\
$1.3 / 2.7$ & 0.94 & 1.64 \\
\hline
\end{tabular}

${ }^{a}$ The PEO $\left(0_{0}\right)$ indicates the ratio of $\mathrm{PEO}\left(M_{1}=600,000\right)$ and $\mathrm{PEO}\left(M_{\mathrm{r}}=\right.$ $8,000,000$ ).

the DNA molecules of Hanwoo and Holstein amplified with their corresponding MS narkers (i.e.. $a=3 . b=2$ and $c=4$ ) were separated within 33 min through the CGE-LIF system (Fig. 5). A breed of Hanwoo was identified based on Table 4 which shows a database of the gene frequencies of Hanwoo 
Table 3. The migration times of the 2-bp DNA ladder in the sieving gel matrix containing a misture of $1.3 \% \mathrm{PEO}(\mathrm{Mr}=600,000)$ and $1.9 \% \mathrm{PEO}$ $\left(M_{\mathrm{T}}=8,000,000\right)$

\begin{tabular}{lcccc}
\hline Locus & Size $(\mathrm{bp})$ & Migration time $(\mathrm{min})^{a}$ & Size $(\mathrm{bp})$ & Migration time $(\mathrm{min})^{a}$ \\
\hline TGLA227 & 82 & $25.43 \pm 0.04$ & 105 & $26.81 \pm 0.03$ \\
BM2113 & 125 & $28.00 \pm 0.04$ & 156 & $29.77 \pm 0.05$ \\
TGLA53 & 158 & $29.88 \pm 0.03$ & 192 & $31.93 \pm 0.09$ \\
ETH10 & 209 & $32.71 \pm 0.03$ & 228 & $34.03 \pm 0.02$ \\
SPS115 & 246 & $35.05 \pm 0.02$ & 257 & $35.86 \pm 0.02$ \\
\hline
\end{tabular}

"Migration time shows the mean \pm standard deviation $(n=3)$.

Table 4. Gene frequencies of Hanwoo and Holstein

\begin{tabular}{|c|c|c|c|c|c|c|c|}
\hline Locus & Size (bp) & Hanwoo & Holstein & Locus & Size (bp) & Hanwoo & Holstein \\
\hline \multirow[t]{7}{*}{$\mathrm{ETH}_{3}$} & 115 & 0.0185 & & TGLA122 & 154 & & 0.0250 \\
\hline & 117 & 0.3056 & 0.5750 & & 160 & 0.0132 & \\
\hline & 119 & 0.2778 & & & 164 & & 0.0250 \\
\hline & 121 & 0.0833 & & & 166 & & 0.3000 \\
\hline & 125 & 0.1389 & 0.0750 & & 172 & & 0.0250 \\
\hline & 127 & 0.1759 & 0.2000 & & 174 & & 0.0500 \\
\hline & 129 & & 0.1500 & & 184 & & 0.1000 \\
\hline \multirow[t]{8}{*}{ ETH225 } & 140 & & 0.0833 & TGLA227 & 78 & 0.2791 & \\
\hline & 142 & 0.0833 & 0.0278 & & 86 & 0.1512 & 0.1000 \\
\hline & 144 & 0.4332 & 0.0556 & & 90 & 0.3488 & 0.0250 \\
\hline & 146 & 0.1481 & 0.0833 & & 94 & 0.2209 & 0.2500 \\
\hline & 148 & 0.1944 & 0.4167 & & 100 & & 0.6250 \\
\hline & 150 & 0.1296 & 0.2778 & $\mathrm{BM} 2113$ & 126 & 0.0093 & 0.2750 \\
\hline & 152 & & 0.0556 & & 128 & 0.0833 & 0.1500 \\
\hline & 158 & 0.0093 & & & 134 & 0.0556 & \\
\hline \multirow[t]{6}{*}{$\mathrm{BMl} 824$} & 180 & 0.0093 & 0.1500 & & 136 & 0.2130 & 0.4000 \\
\hline & 182 & 0.4167 & 0.2250 & & 1.38 & 0.2500 & 0.1000 \\
\hline & 184 & 0.4074 & 0.2500 & & 140 & 0.3796 & 0.0750 \\
\hline & 186 & 0.0278 & & & 142 & 0.0093 & \\
\hline & 190 & 0.1296 & 0.3500 & ETH10 & 212 & 0.0278 & \\
\hline & 192 & 0.0093 & 0.0250 & & 214 & & 0.0250 \\
\hline \multirow[t]{7}{*}{ TGLA126 } & 111 & 0.0172 & & & 218 & 0.2870 & 0.1500 \\
\hline & 115 & 0.2759 & 0.4500 & & 220 & 0.2500 & 0.6250 \\
\hline & 117 & 0.1724 & 0.4250 & & 222 & 0.1759 & 0.0250 \\
\hline & 119 & 0.0172 & & & 224 & 0.0556 & 0.1250 \\
\hline & 121 & 0.2069 & 0.1250 & & 226 & 0.2037 & 0.0500 \\
\hline & 123 & 0.2069 & & SPS115 & 245 & 0.0093 & \\
\hline & 125 & 0.1034 & & & 247 & 0.4259 & 0.5625 \\
\hline \multirow[t]{7}{*}{ TGLA 122} & 134 & 0.0921 & & & 249 & 0.0833 & \\
\hline & 138 & 0.0263 & & & 251 & 0.1204 & 0.2188 \\
\hline & 140 & 0.0789 & & & 253 & 0.0741 & \\
\hline & 142 & 0.1842 & & & 255 & 0.1574 & 0.1250 \\
\hline & 144 & 0.3553 & 0.2750 & & 257 & & 0.0938 \\
\hline & 150 & 0.1974 & 0.1000 & & 259 & 0.1296 & \\
\hline & 152 & 0.0526 & 0.1000 & & & & \\
\hline
\end{tabular}


and Holstein for each MS marker. ${ }^{23}$ Because breeds of cattle have variable polymorphic loci. Hanwoo was able to be distinguished from the other breed through the CGE-LIF assay method based on the DNA mobilities of the MSs.

\section{Conclusions}

The genetic differences between two cattle breeds. Korean cattle (Hanwoo) and Holstein, were identified by a gene analy'sis technique using MSs based on their capillary gel electrophoretic DNA mobilities determined by CGE-LIF detection. The species-specific genes were separated within $33 \mathrm{~min}$ using the CGE-LIF detector under the optimum conditions, viz. an electric field of $120 \mathrm{~V} / \mathrm{cm}$ : fused-silica capillary with an inner diameter of $75 \mu \mathrm{m}$. outer diameter of $365 \mu \mathrm{m}$ and total length of $50 \mathrm{~cm}$ dynamically coated with $1.0 \%(w / \mathrm{w})$ PVP $\left(M_{\mathrm{t}}=\right.$ $1.000 .000)$ : sieving gel matrix consisting of a mixture of $1.3 \%$ $(\mathrm{w} / \mathrm{v})$ PEO $\left(\mu_{\mathrm{r}}=600,000\right)$ and $1.9 \%(\mathrm{w} / \mathrm{v})$ PEO $\left(\mu_{\mathrm{r}}=\right.$ 8.000 .000 ). Although $\mathrm{MSs}$ are useful in the identification of species-specific genes. it is not easy to achieve the baseline separation of DNA molecules with a serial gap of 2-bp DNA. However the use of mixed sieving gel polymers with different molecular weights showed good separation results. which enabled us to identify the species-specific genes of Hanwoo and Holstein. The CGE-LIF assay method based on the DNA mobilities of the MSs can be used for a wide range of applications such as the diagnosis of diseases and the differentiation of genetic polymorphisms of species. as well as the identification of cattle breeds.

Acknowledgments. This work was supported bỵ a grant (Code 20070501034006) from the BioGreen 21 Program. Rural Development Administration. Republic of Korea.

\section{References}

1. Aguzzi, A: Heikenwalder, M; Miele, G. J. Clin. Invest. 2004, $11+153$.

2. Yang, W.-C.: Yeung, E. S.: Schunert, M. J. Electrophoresis 2005 , 26,1751

3. Yoog, J. R: Kim, H. K.: Park, H. K.; Yoon, H. S.: Seol, D. S.; Jung. C. K. Hanwoo. Hyang Moon Sa, Seoul, 1985.
4. Yoon, D.: Park, E. W.; Cho, Y. M.: Cheong. I. C.: Im, S. K. J. Anm. Sci. \& Techlol. 2007, 49, 429.

5. Yoon, D.; Park, E. W; Lee, S. H.; Lee, H. K.; Oh, S. T.; Cheong I. C.; Hong, K. C. J. Anim. Sci. \& Techol 2005, 47, 341

6. Chung, E. R.; Chung, K. Y. Korean J. Food Sci. Ani. Resom: 2014, 24,355

7. Abdel-Rahman, S. M.; Almed, M. M. M. Food Control 2007, 18,1246 .

8. Miretti, M. M.; Ferro, T. A.; Lara, M. A.; Contel, E. P. B. Biochem. Genet. 2001, 39, 311.

9. Yeo, I. S.: Lee, I. S.; Lee, C. H.: Jung, Y. I.; Nam, D. H. Biotechnol. Bioprocess Eng. 2000, 5,23

10. Oh, H.-R; Lee, C.-S.; Sang, B.-C; Song, K.-T. Jour Agri. Sci. 2006, 33, 1

11. Chung, E. R.; Kim, W. T.: Kim, Y. S.: Han, S. K. J. Anim. Sci. \& Techol 2000, 42,391

12. Ajmone-Marsan, P; Valentini, A.; Cassandro, M.; Vecchiotti-Antaldi, G.; Bertoni, G.; Kuiper, M. Anim. Genet. 1997, 28, 418.

13. Fries, R.; Eggen, A.; Stranzinger, G. Genomics $1990,8,403$.

14. Hong, I. M.: Chae, S. H.: Oriero, N.: Larkin, D. M.: Choi, C. B.; Lee, I. Y.; Lewin, H. A.; Bae, I. H.; Choi, I.; Yeo, I. S. J. Genet. $2005,84,329$

15. Kim, K. S.; Eum, J. H.; Choi, C. B. J. Anm. Sci. \& Technol. 2001. 43,599

16. Botstein, D.; White, R. L.; Skolnick, M.; Davis, R. W. Am. J. Hum. Genet. 1980, 32, 314.

17. Powell, W.: Morgante, M.: Andre, C.: Hanafey, M.: Vogel, T.; Tingey, S.; Rafalski, A. Hol Breed 1996, 2, 225.

18. Arslan, A.; Thak, I.; Calicioglu, M:; Karahan, M. J. Mhsscle Foods 2005, 16, 37.

19. Vos, P.: Hogers, R.: Bleeker, M.: Reijans, M.: van de Lee, T.; Hones, M.; Frijters, A.: Pot, J.: Peleman, J:- Kulper, M:; Zabeaul, M. Aucleic .1cids Res. 1995, 23,4407,

20. Li, K.; Chen, Y; Moran, C; Fan, B.; Zhao, S.; Peng, Z. Amm. Genet $2000,31,322$.

21. Lee, T. M.; Nahm, S. H.: Kim, Y. M: Kim, B. D. Theor Appl. Genet. 2004, 108,619.

22. Go, H.; Lee, M.: Oh, D.: Kim, K.S.: Cho, K.: Yoo, D. J.: Kang, S. H. Bull. Kowan Chem. Soc. 2009, 30, 2141.

23. Patent number: KR 10-2007-0066352

24. Rehout, V.; Hradecká, E; Čítek, J. Czech J. Anim. Sci. 2006, 51 , 503

25. Rejduch, B.: Kozubská-Sobocińska, A.: Radko, A.: Rychlik, T:; Slota, E. J. Anim. Breed. Genet. 2004, 121, 197.

26. Kaneta, T: Ueda, T.; Hata, K.; Imasaka, T. J. Chromatogr: A 2006, 1106,52

27. Radko, S. P.: Chrambach, A. J. Phs Chem 1996, 100, 19461

28. Kim, Y.: Yeung. E. S. J. Chromatogr \& 1997, 781, 315. 